\title{
THE GERMAN FEDERAL LAW ON INTEGRATION
}

\author{
ARNDT KÜNNECKE
}

\begin{abstract}
The German Federal Act on Integration of 2016 is a political reaction to the migration crisis of 2015. It aims to facilitate the integration of refugees into the German society. Its guiding principle is that of 'support and challenge': Refugees who have good prospects of being allowed to stay permanently will be eligible to take integration courses and to take advantage of job and training opportunities sooner than before. However, they are also required to work on their own integration. If they do not meet their duties to cooperate their benefits will be curtailed. In this article we deal with provisions regulating the legal status of migrants in the complex process of integration.
\end{abstract}

Keywords: foreign nationals; integration; migration; asylum; citizenship; integration policy

Klíčová slova: cizinci; integrace; migrace; azyl; státní občanství; integrační politika

DOI: $10.14712 / 23366478.2018 .7$

\section{INTRODUCTION}

Since the foundation of the Federal Republic of Germany in 1949, millions of immigrants have arrived on its territory. However, Germany has generally not been considered a "classical immigration country". Instead, Germany is often classified as a typical example of a "labour recruiting country". ${ }^{1}$ Between the years of 1955 and 1968, Germany concluded foreign labour recruiting contracts with several countries: Italy (1955), Spain and Greece (1960), Turkey (1961), Morocco (1963), Portugal (1964), Tunisia (1965) and Yugoslavia (1968). By 1973 foreign labour recruitment stopped because of the economic recession caused by the oil crisis. Between 1960 and 1973, the foreign work force in Germany increased from $1.5 \%$ up to $11.9 \% .^{2}$ Although the German government was aware that a huge amount of guest workers, and foreigners in general, opted to stay in Germany instead of returning to their home countries, the German government was reluctant to admit that Germany had in fact become an "immigration country". Therefore, the integration of migrants was lacking and there was no clear path to citizenship, even for long-term resident migrants, or their children. Only with the Migration Act in 2005, did the German government formally recognise that Germany had indeed become an "immigration country". However, there is still no separate immigration code in German Law.

CHIN, R.: The Guest Worker Question in Postwar Germany. Cambridge, 2007, p. 25.

2 See: MARTINEZ CALERO, M. - ROHLOFF, S. A.: Bürgerschaftliches Engagement und BildungserfolgSpanische MigrantInnen der ersten Generation und ihre Nachkommen in Deutschland. Wiesbaden, 2016, p. $186 \mathrm{f}$. 
In 2015, Germany's population increased by 978,000 , to a total population of 82.2 million. This was an increase of $1.2 \%$ compared to 2014 . The population growth in 2015 represented the largest growth in population that Germany has experienced since 1992 and resulted mainly from an increase in immigration. ${ }^{3}$ In fact, immigration to Germany was higher than ever before with a total of 2.14 million people immigrating to Germany in 2015, representing an increase of $46 \%$ compared to 2014 . $45 \%$ of immigrants originated from EU Member States, 13\% from other European countries, 30\% from Asia, and 5\% from Africa. ${ }^{4}$ Without immigration, Germany's population would have declined.

Currently, slightly over 17 million people in Germany - accounting for $21 \%$ of the country's total population - have a "migrant background". This represents a $4.4 \%$ increase compared to the year 2014. ${ }^{5}$ A person with a "migrant background" is defined by the German Federal Statistical Office as someone who was not born a German citizen, or who has at least one parent who was not born with German citizenship. This includes foreigners, naturalised Germans, ethnic German re-settlers, and descendants of these groups. ${ }^{6}$ According to the German Residence Act, "foreigner" is defined as anyone who is not German within the meaning of Art. 116 I of the German Basic Law. ${ }^{7}$ The definition includes anyone who only has a foreign passport, but excludes people with dual citizenship, stateless persons, those with uncertain citizenship, and ethnic German re-settlers.

\section{THE GERMAN CONCEPT OF INTEGRATION}

The German concept for the integration of foreigners into German society covers various areas. Generally, it is based on imparting values of the liberal democratic fundamental order and on imparting knowledge about German history, culture and legal order. Foreigners who show their willingness to stay in Germany are offered various forms of residence permits. The ones who are not able to financially take care of themselves, are provided with supplementary social benefits (e.g. for food, clothes, health, and housing). Another important element of the integration of foreigners into the German society is their acquisition of German language. To support the efforts of

3 STATISTISCHES BUNDESAMT: Pressemitteilung vom 26. August 2016 - 295/16. 82,2 Millionen Einwohner am Jahresende 2015 - Bevölkerungszunahme durch hohe Zuwanderung. Available online at: https://www.destatis.de/DE/PresseService/Presse/Pressemitteilungen/2016/08/PD16_295_12411pdf .pdf?_blob=publicationFile [accessed on 17.11.2017].

4 STATISTISCHES BUNDESAMT: Pressemitteilung vom 14. Juli 2016-246/16. 2015: Höchststände bei Zuwanderung und Wanderungsüberschuss in Deutschland. Available online at: https://www.destatis.de /DE/PresseService/Presse/Pressemitteilungen/2016/07/PD16_246_12421pdf.pdf?_blob=publicationFile [accessed on 17.11.2017].

5 STATISTISCHES BUNDESAMT: Pressemitteilung vom 16. September 2016 - 327/16. Bevölkerung mit Migrationshintergrund auf Rekordniveau. Available online at: https://www.destatis.de/DE/PresseService/Presse/Pressemitteilungen/2016/09/PD16_327_122pdf.pdf?_blob=publicationFile [accessed on 17.11.2017].

6 STATISTISCHES BUNDESAMT: Pressemitteilung vom 26. August 2016 - 295/16. 82,2 Millionen Einwohner am Jahresende 2015 - Bevölkerungszunahme durch hohe Zuwanderung.

$7 \S 2$ German Residence Act. 
foreigners learning the German language, grants and supportive measures for education and training are offered by the German state. In addition, to enable foreigners to support themselves, the German government provides supportive measures for integration in the domestic labour market, for example vocational training or job related German language courses.

\section{LEGAL FRAMEWORK OF INTEGRATION IN GERMANY}

Due to the lack of a separate integration code, the rules on the integration of foreigners in German law are spread over many different legal sources: the Act on Foreigners of $1965,{ }^{8}$ the Law on EEC Residence of $1969,{ }^{9}$ the Asylum Procedure Act of 1982, ${ }^{10}$ the Return Assistance Act of 1983, ${ }^{11}$ the revision of the Act on Foreigners of $1990,{ }^{12}$ the Asylum Seekers Benefits Act of $1993,{ }^{13}$ the Central Register of Foreigners Act of 1994, ${ }^{14}$ the Code of Social Law (Book III) of 1997, ${ }^{15}$ the Code of Social Law (Book II) of 2005, ${ }^{16}$ the Code of Social Law (Book XII) of 2005, ${ }^{17}$ the Residence Act from 2005, ${ }^{18}$ the Migration Act of 2005, ${ }^{19}$ and the Integration Act of 2016. ${ }^{20}$

\section{FEDERAL ACT ON INTEGRATION OF 2016}

As a political reaction to the migration crisis of 2015, the German government put the establishment of a Federal Act on Integration onto the agenda. The act was discussed and adopted by the Federal Government at its special cabinet meeting in Schloss Meseberg, a castle north of Berlin, on 25 May 2016..$^{21}$ The Federal Act on Integration itself entered into force on 6 August 2016.

8 Ausländergesetz vom 28. April 1965, BGBl. III at 2006.

9 Gesetz über Einreise und Aufenthalt von Staatsangehörigen der Europäischen Wirtschaftsgemeinschaft (AufenthG/EWG) vom 22. Juli 1969, BGBl. I at 927.

10 Asylverfahrensgesetz vom 16. Juli 1982, BGB1. I at 946.

11 Rückkehrhilfegesetz vom 28. November 1983, BGBl. I at 1377.

12 Gesetz zur Neuregelung des Ausländerrechts vom 9. Juli 1990, BGB1. I at 1354.

13 Asylbewerberleistungsgesetz vom 30. Juni 1993, BGB1. I at 1074.

14 Ausländerzentralregistergesetz vom 2. September 1994, BGB1. I at 2265.

15 Sozialgesetzbuch Drittes Buch (III) - Arbeitsförderung - vom 24. März 1997, BGBl. I at 594.

16 Sozialgesetzbuch Zweites Buch (II) - Grundsicherung für Arbeitsuchende - vom 24. Dezember 2003, BGB1. I at 2954.

17 Sozialgesetzbuch Zwölftes Buch (XII) - Sozialhilfe - vom 27. Dezember 2003, BGBl. I at 3022.

18 Gesetz über den Aufenthalt, die Erwerbstätigkeit und die Integration von Ausländern im Bundesgebiet (Aufenthaltsgesetz) vom 25. März 2005, BGBl. I at 721.

19 Gesetz zur Steuerung und Begrenzung der Zuwanderung und zur Regelung des Aufenthalts und der Integration von Unionsbürgern und Ausländern (Zuwanderungsgesetz) vom 30. Juli 2004, BGBl. I at 1951.

20 Integrationsgesetz vom 31. Juli 2016, BGB1. I at 1939.

21 For details about the aims and purposes of the Integration Act, see: Meseberger Erklärung zur Integration, available online at: https://www.bmi.bund.de/SharedDocs/downloads/DE/veroeffentlichungen/2016/mese berger-erklaerung.pdf;jsessionid=31B3B539E7F4DED29D69012E196D6D6C.2_cid295?_blob $=$ publicationFile $\& \mathrm{~V}=1$ [accessed on 17.11.2017]. 
The main aim of the Integration Act, and its accompanying Regulation on the Integration Act, ${ }^{22}$ was to facilitate the integration of refugees into the German society. The Act was based on the motto "support and challenge" (Fördern und Fordern) that marks the continuation of the policy under the same title, which had already been introduced in 2005 in the Migration Act. ${ }^{23}$

Refugees who show the potential to integrate and have a good chance of permanently staying in Germany are provided with easier and faster access to integration classes and employment opportunities, while refugees who refuse to cooperate face a reduction in benefits.

The statutory instrument that forms part of the Integration Act sets out details regarding integration courses and the suspension of the labour market priority check. ${ }^{24}$

Since the Federal Act on Integration did not establish a separate Integration Code, it amended the following laws: Book II of the Code of Social Law (dealing with the basic cover of social protection for jobseekers), Book III of the Code of Social Law (dealing with labour promotion), Book XII of the Code of Social Law (dealing with social assistance), the Asylum Seekers Benefits Act, the Residence Act, the Asylum Act, and the Central Register of Foreigners Act.

The Federal Act of Integration itself includes several points which are meant to facilitate the integration of foreigners into German society. To better illustrate the scope and impact of the Federal Act, the following paragraphs summarise some of its key content:

\section{UNIFORM RULE ON PERMISSION TO RESIDE}

Foreigners who have been recognised as being entitled to asylum, who have refugee status, who have been granted subsidiary protection or an initial temporary residence permit are granted permission to reside when they are issued with their arrival certificate. $^{25}$ This ensures that they have legal certainty during their stay in Germany and are given early access to the labour market and integration courses.

The Federal Office for Migration and Refugees $(B A M F)$ decides in asylum proceedings on four different types of protection: the right of asylum, refugee protection, subsidiary protection, and prohibition of deportation. Depending on the type of protection, these persons are granted a residence permit for a term of one to three years with the possibility of an extension or transformation into permanent residence. Depending on the status of the foreigner residing in Germany, four different types of permissions to reside exist in German Federal Law:

The temporary resident permit (Aufenthaltsgestattung) gives foreign persons in Germany a temporary permission to reside. This type of permission to reside is granted to

22 Verordnung zum Integrationsgesetz vom 31. Juli 2016, BGBl. I at 1950.

23 DEINHARD, M.: Das Recht der Staatsangehörigkeit unter dem Einfluss globaler Migrationserscheinungen. Berlin, 2015, p. 124.

24 See: Verordnung zum Integrationsgesetz vom 31. Juli 2016.

$25 \S \S 55,63 \mathrm{a}$ German Asylum Act. 
refugees, or asylum applicants, who are still in the asylum proceedings. ${ }^{26}$ It entitles them to live in Germany until the asylum proceedings have been completed, that is until the decision has been taken on the asylum application. For refugees, this type of residence permit lasts for the duration of their refugee status. Persons who have been in Germany for three months with the temporary resident permit, and whose asylum application is pending, can be authorised to take up employment.

The exceptional leave to remain (Duldung) is a residence status, which suspends the deportation of a foreigner living in Germany. ${ }^{27}$ Persons who are not, or are no longer in the asylum proceedings, or those whose applications have been turned down, but whose deportation has been suspended, receive a "certificate of suspension of deportation"(the so-called Duldung) from the immigration authority. A waiting period of three months applies as a matter of principle to authorisation to take up employment with regard to those persons with temporary suspension of deportation status.

The residence permit (Aufenthaltserlaubnis) is a residence title which is issued for a limited period of time and includes the permission to work. ${ }^{28}$ It is granted to persons who want to: undergo training in Germany; who want to work in Germany; who are entitled to remain in Germany for humanitarian or political reasons, or under international law; who are immigrating to Germany for family reasons; who are foreign nationals and former Germans who would like to return to Germany; or who hold a permanent right of residence in another Member State of the European Union. The residence permit can be extended. ${ }^{29}$

The settlement permit (Niederlassungserlaubnis) is the ultimate form of residence permit and grants the right to unlimited permanent stay in Germany. It does not have a time limit and allows its holder to work in Germany as well. To obtain a settlement permit, a foreigner must have had a residence permit for five years and must also fulfil further conditions, for example they must show that they are able to make his/her own living and secure the financial independence of his/her family members, have adequate German language skills, and should not have a criminal record. ${ }^{30}$ In certain circumstances, a settlement permit can be granted without the relevant conditions in relation to periods of time having been met, for example in the case of highly-qualified immigrants.

\section{RESIDENCE RULE PROVIDES BETTER MEANS OF CONTROL}

According to $\S 12 \mathrm{a}$ of the German Residence Act, asylum seekers, refugees, foreigners who have been granted subsidiary protection or who have been granted an initial temporary residence permit, are assigned a place of residence. This residence rule was established because the majority of refugees intended to move to urban centres, which would have made integration there very difficult. ${ }^{31}$

$26 \S 55$ German Asylum Act.

$27 \S 60$ a German Residence Act.

$28 § 7$ German Residence Act.

$29 \S 8$ German Residence Act.

$30 § 9$ German Residence Act.

31 DIE BUNDESREGIERUNG: Integrationsgesetz setzt auf Fördern und Fordern. Available online at: https://www.bundesregierung.de/Content/DE/Artikel/2016/05/2016-05-25-integrationsgesetz-beschlossen .html;jsessionid=9297E62D0EC066FB4549D02A7F2E194E.s3t2 [accessed on 17.11.2017]. 
After being assigned to a municipality, in principle, the foreigner resides in a community accommodation facility for up to 24 months. If an asylum seeker receives benefits from a job centre according to the Asylum Seekers Benefits Act, the administrative agency may obligate him or her to reside in a specific community accommodation facility. There is only one exception: If the foreigner (or his or her spouse/ registered civil partner or a minor child) has taken up or entered into employment that is subject to compulsory social security contributions of at least 15 hours per week with an income, and thus earns approximately $712 €$ per month (these are the monthly average costs of living according to the Code of Social Law), the residency restriction may be cancelled. ${ }^{32}$

Refugees must stay in the federal state (Land) they were assigned to after their arrival for the first three years. ${ }^{33}$ This applies with retroactive effect from 1 January 2016. The federal states (Länder) may assign a specific place of residence to those entitled to protection in these three years. They can also forbid the refugees to move to urban centres of population. However, for exceptional cases, hardship clauses exist.

\section{TAKING INTEGRATION COURSES AT AN EARLY STAGE}

One cornerstone for integration of foreigners into German society is their participation in integration courses. Therefore, the Integration Act facilitates access to integration courses. The possibility of obliging persons entitled to asylum, recognised refugees or subsidiary beneficiaries to participate in integration courses has been extended. For asylum seekers with good chances of staying in Germany it was newly created. ${ }^{34}$

In contrast to the former rules, the waiting period between the participant's registration and the commencement of the course is reduced from three months to six weeks. The integration courses themselves include 600 hours of a language course component and 100 hours of instruction in one orientation course. A special focus is placed on conveying values.

Currently, the right to participate in an integration course expires after one instead of two years. In addition, the prerequisites for higher course capacities, more transparency and more efficient management of the integration course system are created. For example, to generate additional capacity, the maximum number of participants is increased from 20 to 25 persons. If the integration course is successfully completed, foreigners may also attend vocation-related German courses.

If foreigners who are able to work, but who are not gainfully employed, do not attend the course without any excuse, they must expect the curtailing of their benefits. ${ }^{35}$

32 See: WELTE, H. P.: Wegweiser Rechtsänderungen im Ausländerrecht: Kommentar zu aktuellen Gesetzesreformen: Aufenth G, AsylG und BeschV. Walhalla, 2016, p. 43.

33 Art. 5 German Federal Act on Integration creating § 12a German Residence Act.

34 Art. 4 German Federal Act on Integration creating $\S 5$ b German Asylum Seekers Benefits Act.

35 Art. 4 German Federal Act on Integration creating $\S \S 5$ a III, 5b II German Asylum Seekers Benefits Act. 
Training-related assistance, assisted training, and pre-vocational training programs are available sooner than before, depending on the target group. Vocational training grants and training stipends are available to certain groups for the first time.

Asylum seekers with good chances of staying in Germany and foreigners with an exceptional leave to remain become eligible for education or training grants pursuant to $\S 132$ of Book III of the Code of Social Law. For example, this includes assistance during training, prevocational training programs, and subsidised education for a limited term until the end of 2018 to make it easier for them to complete in-house vocational training.

Vocational training assistance and training grants can be given to asylum seekers after they have been staying in Germany for 15 months, unless they still live in a reception centre. ${ }^{36}$ These two services aim to help, for example, when the training grant is not sufficient for housing and livelihood. In the first 15 months, benefits are available for asylum seekers according to the Asylum Seekers Benefits Act. Benefits are also available during an apprenticeship.

Foreigners with an exceptional leave to remain, can enjoy support by the German state in the form of training-accompanying aids and assisted training after a twelve months' stay in Germany. ${ }^{37}$ This is three months earlier than before. They must only provide an apprenticeship training position, an initial qualification, or a concrete commitment to a position.

\section{LEGAL CERTAINTY WHILE UNDERGOING VOCATIONAL TRAINING}

According to $\S 18 \mathrm{a}$ and $\S 60 \mathrm{a}$ of the German Residence Act, refugees of any age have legal certainty for the time of their vocational training, as they receive an exceptional leave and they cannot be deported for the entire duration of their training. The previous age limit of 21 years, which had to be reached before being entitled to start any vocational training, was repealed.

Those who drop out of training receive a six-month extension of their tolerated-person status to give them a chance to find a new vocational training place. ${ }^{38}$ The right of residence will be revoked if the subsequent employment relationship is terminated, or if the foreigner is convicted of a wilful crime.

Foreigners who have completed vocational training successfully receive a tolerated-person status for six months to look for a job. Those who have successfully completed vocational training are entitled to residence in Germany for a further two years, if they find a job which reflects their new qualification. ${ }^{39}$ This mechanism is known as the " $3+2$ rule". Thereafter, a foreigner has the right to the issuance of a settlement permit.

36 Art. 1 German Federal Act on Integration amending § 132 I Nr. 2 Book III of the German Code of Social Law.

37 Art. 1 German Federal Act on Integration amending § 132 II Book III of the Code of Social Law.

38 Art. 5 German Federal Act on Integration amending § 60a II 4 German Residence Act.

39 Art. 5 German Federal Act on Integration creating § 18a Ia German Residence Act. 
As long as the asylum seeker resides in a reception centre, a prohibition on working in accordance with $\S 61 \mathrm{I}$ of the German Asylum Act shall apply. After a threemonth waiting period, a work permit may be granted by the Foreigners' Registration Office for a dependent job in accordance with $\S 61 \mathrm{I}$ of the German Asylum Act.

To give refugees and asylum seekers opportunities for meaningful activities during their administrative procedures, the federal government launched a Refugee Integration Measures Programme for 100,000 refugees and asylum seekers in August 2016. From 2017 to 2020, the federal government will provide 300 million Euros annually.

These integration measures include work for refugees and asylum seekers in their own accommodation facilities, for instance at the food serving counter, in the clothing store, or at the cleaner's. However, first and foremost, refugees are supposed to work outside their accommodation - for example for the municipality helping to cultivate green spaces. They receive an allowance of 80 cents per hour. The integration measures can last up to six months in total and up to 30 hours a week. It is important to mention that these integration measures do not constitute an employment relationship for legal purposes. ${ }^{40}$

Asylum seekers from safe countries of origin, such as the Member States of the European Union, Albania, Bosnia and Herzegovina, Ghana, Kosovo, Macedonia, Montenegro, Senegal and Serbia, as well as persons whose enforceable duty it is to leave Germany are excluded from these measures. ${ }^{41}$

If refugees or asylum seekers who are able to work, but who are not gainfully employed, do not attend the measure without any excuse, they must expect the curtailing of their social benefits. ${ }^{42}$

\section{LABOUR MARKET PRIORITY CHECK SUSPENDED}

The labour market priority test is being suspended for three years for asylum applicants and those with "tolerated person" status, enabling them to also engage in temporary agency work. ${ }^{43}$ This removes the need to carry out a time-consuming check as to whether an EU citizen could be considered for the job in question before the position is filled.

To avoid any potential negative impact in regions where the labour market is tight, the Federal States (Länder) are to decide in which employment agency districts this arrangement applies. ${ }^{44}$

For vocational training, internships for further training purposes, voluntary service or the employment of highly qualified persons, no consent of the employment agency is needed for the foreigners to start their job.

40 Art. 1 German Federal Act on Integration creating § 421a Book III of the German Code of Social Law.

41 Art. 4 German Federal Act on Integration creating § 5a I German Asylum Seekers Benefits Act.

42 Art. 4 German Federal Act on Integration creating § 5a III German Asylum Seekers Benefits Act.

43 Art. 1 Regulation on the German Federal Act on Integration amending § 32 Employment Regulation.

44 Art. 1 Regulation on the German Federal Act on Integration creating Annex to $§ 32$ Employment Regulation. 


\section{SETTLEMENT PERMIT DEPENDENT ON INTEGRATION}

The right of permanent residence, in the form of a settlement permit for an unlimited period, is only granted to recognised refugees and persons entitled to be granted asylum after five years if, in addition to other conditions (e.g. proof of age, proof of integration efforts, sufficient housing, etc.), he or she can prove sufficient knowledge of the German language (level A2) and can secure his or her livelihood predominantly by himself or herself. 45

In cases of a particularly successful integration, a settlement permit may be issued after three years. This possibility is meant to create a special incentive for integration. For example, someone who speaks German at a high level (level C1 command of the German language) and earns his or her living largely independently is outstandingly integrated.

The time until completion of the asylum procedures is deducted from the period required for the settlement permit to be issued.

\section{RESIDENCE FOR HUMANITARIAN REASONS}

If asylum seekers receive subsidiary protection in accordance with $\S 4 \mathrm{I}$ of the German Asylum Act, they may, in accordance with $§ 25$ II 1 of the German Residence Act, be granted a residence permit if they can secure their livelihoods themselves. The residence permit is initially granted for one year and then extended for an additional two years.

A settlement permit is granted if refugees have been in possession of a residence permit for five years, and the other conditions in accordance with § $26 \mathrm{IV}$ of the German Residence Act in conjunction with § 9 II 1 of the German Residence Act (e.g. securing of one's own livelihood, verification of pension provision, verification of integration, adequate housing, etc.), are fulfilled.

\section{RESIDENCE FOR WELL-INTEGRATED YOUNG PERSONS}

Under $\S 25 \mathrm{a}$ I of the German Residence Act, young persons, or adolescents with an exceptional leave to remain, will receive a residence instrument if they are well-integrated into German society. A precondition is that their exceptional leave to remain is still valid. In addition, the young persons or adolescents must have successfully attended a school in the federal territory for four years, or acquired a recognised school or vocational qualification.

The application for the residence title may be submitted by young persons who have reached the age of 15 , but who are not older than 21 .

\section{RESIDENCE UPON SUSTAINABLE INTEGRATION}

Foreigners who have sustainably integrated themselves into the living conditions of Germany, but for years have only possessed an exceptional leave to remain,

45 Art. 5 German Federal Act on Integration amending § 26 III German Residence Act. 
are to be granted a residence permit in accordance with $\S 25 \mathrm{~b}$ of the German Residence Act. At the time of granting, the foreigner must still have his or her exceptional leave to remain.

The foreigner with an exceptional leave to remain must have lived in Germany for eight years, or six years if he or she is a minor child; must affirm the free democratic basic order; must have sufficient oral knowledge of German at level A2; must have secured his or her livelihood through gainful employment, or this is to be expected in the future; and he or she must not have committed any criminal offences. ${ }^{46}$

\section{SHARE OF THE FOREIGN POPULATION TO BE INTEGRATED IN GERMANY}

Since the beginning of 2014, more than 1.6 million people have applied for Asylum in Germany. ${ }^{47}$ According to official data of the Federal Office for Statistics, by the end of 20161.6 million persons seeking protection were registered in Germany. ${ }^{48}$ Compared to the numbers of 2014 , this was an increase of 851,000 persons or $113 \%$. Data for the year 2017 is not available yet. Those seeking protection are: Refugees recognised under the Geneva Convention; beneficiaries of subsidiary protection (i.e. people with limited protection status); and asylum seekers (i.e. those who still want to apply for asylum or wait for an asylum application). The group also includes rejected asylum seekers who are being tolerated, have not yet left, or have not yet been deported. According to the statistics, about half of all those seeking protection come from three countries of origin: Syria, Afghanistan and Iraq. Most people with rejected asylum applications come from Serbia and Albania. At the end of 2016, there were 573,000 (36\%) people seeking protection whose asylum application had not yet been decided upon. 872,000 people seeking protection (54\%) had a humanitarian residence permit and thus a recognised protection status. However, for most of them $(600,000$ of the 872,000$)$, this recognition was only temporary. The application for asylum was rejected for 158,000 people seeking protection. Therefore, these persons were without protection status and in principle had to leave the country. However, in $75 \%$ of those cases $(118,000$ of those $158,000)$, this duty to leave was temporarily suspended because of a temporary leave to remain. ${ }^{49}$

46 § $25 \mathrm{~b}$ I German Residence Act.

47 See: BUNDESAMT FÜR MIGRATION UND FLÜCHTLINGE: Asylgeschäftsstatistik (01-11/17), available online at: http://www.bamf.de/SharedDocs/Anlagen/DE/Downloads/Infothek/Statistik/Asyl /hkl-antrags-entscheidungs-bestandsstatistikl-kumuliert-2017.pdf? blob=publicationFile [accessed on 17.12.2017]; BUNDESAMT FÜR MIGRATION UND FLÜCHTLINGE: Das Bundesamt in Zahlen 2016. Asyl, Migration und Integration. Berlin, 2017, p. 11, available online at: http://www.bamf.de/Shared Docs/Anlagen/DE/Publikationen/Broschueren/bundesamt-in-zahlen-2016.pdf?_blob=publicationFile [accessed on 17.12.2017].

48 BUNDESAMT FÜR MIGRATION UND FLÜCHTLINGE: 1,6 Millionen Schutzsuchende in Deutschland am Jahresende 2016. Available online at: https://www.destatis.de/DE/PresseService/Presse/Pressemittei lungen/2017/11/PD17_387_12521.html [accessed on 17.12.2017].

49 BUNDESAMT FÜR M̄IGRATION UND FLÜCHTLINGE: 1,6 Millionen Schutzsuchende in Deutschland am Jahresende 2016. 
According to the statistics, every sixth foreigner in Germany is a person seeking protection. Almost two-thirds of the 1.6 million people seeking protection are male. For the foreign population in total, the percentage of males is $53 \%$, while in the whole country it is only $49 \%$. The average age of those seeking protection is 29.4 years. By contrast, the foreign population is on average 37.6 years old, whereas the average age of the total population is 44.2 years. ${ }^{50}$

\section{APPROXIMATE COSTS OF THE INTEGRATION MEASURES}

One topic of high relevance concerning the new Federal Act on Integration is the costs of integration and the integration measures being provided by the act. As the costs related with the integration of nearly two million immigrants who arrived in Germany between 2014 and the end of 2017 are enormous, the German federal government is reluctant to publish the real costs of the refugee crisis in a clear and comprehensible manner. Instead it places the costs in several budgets, refers to many different statistics and administrative responsibilities, and makes it nearly impossible to figure out the total costs for the integration of migrants in Germany. ${ }^{51}$ As the Federal Republic of Germany is known worldwide for its accuracy, exactness, and love of order, this can only be explained as the government's fear that its own citizens might start questioning and opposing the official welcoming culture (Willkommenskultur).

In total, since 2014 approximately two million immigrants have come to Germany as refugees or asylum seekers. All of them, no matter what kind of residence status they have and no matter how long they intend to stay in Germany, benefit from integration measures being provided by the new Federal Act on Integration.

To cope with the practical challenges of the Federal Act on Integration, there is a need for approximately 680,000 measures of vocational training, 180,000 places in kindergartens, 2,400 new primary schools, 15,000-30,000 new teachers, 15,000 new policemen, and 2,000 new judges at administrative courts. ${ }^{52}$ However, these are just some of the major positions of the infrastructural needs to manage the demands of the high number of immigrants in Germany since 2014. Together with other measures, and especially with supplying the refugees and asylum seekers with their everyday needs like food, clothes and accommodation, there is a much higher financial burden.

50 BUNDESAMT FÜR MIGRATION UND FLÜCHTLINGE: 1,6 Millionen Schutzsuchende in Deutschland am Jahresende 2016.

51 BOK, W.: Die Flüchtlingskosten sind ein deutsches Tabuthema. Neue Züricher Zeitung, 15. 9. 2017, available online at: https://www.nzz.ch/meinung/kommentare/die-fluechtlingskosten-sind-ein-deutsches -tabuthema-ld.1316333 [accessed on 22.11.2017]; Statement of Reiner Holznagel., President of the German Association of Taxpayers in: Minderjährige Flüchtlinge kosten Städte Milliarden. Die Welt [online], 17. 5. 2016, available online at: https://www.welt.de/politik/deutschland/article155401038/Minderjaehrige-Fluechtlinge-kosten-Staedte-Milliarden.html [accessed on 22.11.2017].

52 See: BOK, W.: Die Flüchtlingskosten sind ein deutsches Tabuthema. Neue Zürcher Zeitung [online], 15. 9. 2017, available online at: https://www.nzz.ch/meinung/kommentare/die-fluechtlingskosten-sind-ein-deut sches-tabuthema-ld.1316333; ELFERING, M. - ZACHARAKIS, Z.: Was kostet die Integration? Zeit Online [online], 21. 10. 2015, available online at: www.zeit.de/wirtschaft/2015-10/kosten-integration -sprackhkurse-fluechtlinge/komplettansicht [accessed on 22.11.2017]. 
According to governmental sources, the German Federal Government will provide altogether 93.6 billion Euros for the supply of refugees in the years 2016-2020. As the Federal States (Länder) claim that they will only get about half of their costs for the supply of refugees reimbursed by the Federal Republic of Germany, the annual costs for the supply of refugees in Germany can be estimated at 30-40 billion Euros. Because of the non-transparency of the federal government's calculations, it remains unclear if the mentioned costs for additional kindergartens, schools, teachers and policemen are included in these sums. ${ }^{53}$ Independent economic institutions, like the German Economic Institute in Cologne (Institut der Deutschen Wirtschaft), or the Kiel Institute for the World Economy (Kieler Institut für Weltwirtschaft), calculate annual costs of approximately 30-55 billion Euros. ${ }^{54}$ Within these calculations, the fixed costs for an integration course per person were determined at 2,000 Euros, the annual costs for the accommodation of a single unaccompanied minor refugee were estimated at 60,000 Euros, for a single adult at 10,000 Euros. ${ }^{55}$

The official costs for the supply and integration of refugees and asylum seekers in Germany in 2016 was 21.7 billion Euros. ${ }^{56}$ In comparison, the total annual budget of the Federal Republic of Germany in 2016 was 316.9 billion Euros. ${ }^{57}$ In comparison with the single items of expenditure, the costs for the supply and integration of refugees and asylum seekers would have been the fifth biggest position in the state's budget in 2016. To cope with the costs for refugees and asylum seekers, every fifth municipality in Germany had to incur new government debts. In addition, every third municipality did not receive any financial support from the federal state to cope with the costs of the high number of refugees and asylum seekers on its territory. ${ }^{58}$

53 See: BOK, W.: Die Flüchtlingskosten sind ein deutsches Tabuthema. Neue Zürcher Zeitung [online], 15. 9. 2017, available online at: https:/www.nzz.ch/meinung/kommentare/die-fluechtlingskosten-sind-ein-deut sches-tabuthema-ld.1316333.

54 HENTZE, T. - SCHÄFER, H.: Flüchtlinge - Folgen für Arbeitsmarkt und Staatsfinanzen. IW-Kurzberichte, 2016, n. 3, p. 2, available online at: https://www.iwkoeln.de/fileadmin/ publikationen/2016/263939 /Kosten_Fluechtlinge_IW-Kurzbericht.pdf [accessed on 22.11.2017]; KIELER INSTITUT FÜR WELTWIRTSC̄HAFT: Simulation von Flüchtlingskosten bis 2022: Langfristig bis zu 55 Mrd. $€$ jährlich. Available online at: https://www.ifw-kiel.de/medien/medieninformationen/2015/simulation-von-fluchtlings kosten-bis-2022-langfristig-bis-zu-55-mrd-20ac-jahrlich [accessed on 22.11.2017].

55 See: ELFERING, M. - ZACHARAKIS, Z.: Was kostet die Integration? Zeit Online [online], 21. 10. 2015, available online at: www.zeit.de/wirtschaft/2015-10/kosten-integration-sprackhkurse-fluechtlinge /komplettansicht [accessed on 22.11.2017]; WOLFSKÄMPF, V.: 60.000 Euro pro Jahr für Unterkunft. Mitteldeutscher Rundfunk [online], 9. 5. 2017, available online at: https://www.mdr.de/nachrichten/politik /inland/kosten-fuer-minderjaehrige-fluechtlinge-100.html [accessed on 22.11.2017].

56 See: FUNK, A. - SCHEFFER, U.: Globale Rechnung. Tagesspiegel, 27. 1. 2017, available online at: http://www.tagesspiegel.de/politik/kosten-der-fluechtlinge-globale-rechnung/19314440.html [accessed on 22.11.2017].

57 BUNDESMINISTERIUM DER FINANZEN: Bundeshaushalt 2016 - Ausgaben nach Einzelplänen, available online at: https://www.bundesfinanzministerium.de/Content/DE/Bilder/Bildstrecken/Mediathek /Infografiken/ Bundeshaushalt/2016/bundeshaushalt-2016-ausgaben-nach-einzelplaenen.html [accessed: 22.11.2017].

58 LORENTZ, B. - FISCHER, D.: Flüchtlingsintegration. Herausforderungen für deutsche Kommunen. 2016 p. 13 f.. Available online at: http:/www.ey.com/Publication/vwLUAssets/EY-fluechtlingsintegration-her ausforderungen-kommunen-2016/\$FILE/EY-fluechtlingsintegration-herausforderungen-kommunen-2016 .pdf [accessed on 22.11.2017]. 
Based on the lowest estimated costs of 30 billion Euros per year, this means that every refugee or asylum seeker in Germany costs the German state a monthly amount of 2,500 Euros. This amount is equivalent to the monthly tax burden of 12 average wage-earners (tax category III with a monthly income of 3,000 Euros) or five singles (tax category I with a monthly income of 3,000 Euros). ${ }^{59}$ Scientific economic calculations carried out by Ifo Institute for Economic Research in Munich (Ifo Institut München) assessed the total costs of each refugee at 450,000 Euros. ${ }^{60}$

\section{CONCLUSION}

The German Federal Act on Integration marks a milestone for the integration of foreigners into German society and the German labour market. After decades of denying that Germany had become an immigration country and that there was not any public need for integrating the foreigners who stayed in Germany, the Integration Act is a step in the right direction, accepting the new realities and trying to cope with the unforeseen situation of millions of immigrants entering the country for political or economic reasons.

However, the German state is still facing huge challenges with the integration of immigrants, especially refugees and asylum seekers. Some assumptions which were made for designing the Integration Act turned out to be wrong, and some just cannot be realised as laid down in the laws. For example, the assumption that the high number of immigrants would solve the problem of the lack of a qualified workforce in Germany turned out to be rather a wish than a description of reality. ${ }^{61}$ About two-thirds of the immigrants already having a job in Germany are employed in low skilled jobs. Every tenth registered jobless person in Germany is a refugee. ${ }^{62}$ And about 600,000 asylum seekers whose asylum procedure is finished are jobless and dependent on social welfare. ${ }^{63}$

Also in the administrative practice, the German authorities are facing some structural problems. On the one hand, administrative personnel are still missing. On the other

59 See: BOK, W.: Die Flüchtlingskosten sind ein deutsches Tabuthema. Neue Zürcher Zeitung [online], 15. 9. 2017.

60 PLICKERT, P.: Ifo-Chef Sinn notfalls für nationale Grenzkontrollen. Frankfurter Allgemeine, 1. 3. 2016, available online at: http://www.faz.net/aktuell/wirtschaft/wirtschaftspolitik/ifo-praesident-hans-we rner-sinn-redet-ueber-fluechtlinge-14098916.html?printPagedArticle=true\#pageIndex_0 [accessed on 22.11.2017]; RAFFELHÜSCHEN, B. - MOOG, S.: Zur fiskalischen Dividende der Flüchtlingskrise. Eine Generationenbilanz. ifo Schnelldienst, 2016, n. 4, pp. 24-29, available online at: https://www.cesifo-group .de/DocDL/sd-2016-04-sinn-etal-migration-2016-02-25.pdf [accessed on 22.11.2017].

61 SIEMS, D.: Warum Flüchtlinge das Fachkräfteproblem nicht lösen. Die Welt, 1. 3. 2016, available online at: https://www.welt.de/wirtschaft/article152779703/Warum-Fluechtlinge-das-Fachkraefteproblem -nicht-loesen.html [accessed on 22.11.2017].

62 OECD: Finding their way. Labour market integration of refugees in Germany. 2017, pp. 22. Available online at: https://www.oecd.org/els/mig/Finding-their-Way-Germany.pdf [accessed on 30.11.2017]; SPECHT, F.: ,, Sind die Flüchtlinge da, wo die Arbeit ist? “. Handelsblatt, 14. 3. 2017, available online at: www.handelsblatt.com/politik/deutschland/integration-auf-dem-arbeitsmarkt-sind-die-fluechtlinge -da-wo-die-arbeit-ist/19516862.html [accessed on 28.12.2017].

63 Wirtschaftsforscher warnt vor Spaltung der Gesellschaft. Die Welt [online], 26. 12. 2017, available online at: https://www.welt.de/wirtschaft/article171904578/Integration-von-Fluechtlingen-DIW-warnt-vor-Spaltung -der-Gesellschaft.html [accessed: 28.12.2017]. 
hand, a considerably high number of administrative staff is not sufficiently qualified for their job. ${ }^{64}$ For example, according to the German Federal Act on Integration, the waiting period for participating in an integration course is reduced to six months. However, in practice, at the beginning of the year 2017 refugees and asylum seekers had to wait for 10.9 weeks, at the end of 2017 even 12.5 weeks, for starting their integration courses. ${ }^{65}$

Last, but not least, even though an Integration Act has existed for about 1.5 years, there is still the danger of a divided society in Germany. Some researchers and officials are warning that if integration fails, in the worst case, Germany is in danger of getting conditions like in France or the United States, where very large parts of the population only have few opportunities and few prospects in their lives. ${ }^{66}$

Therefore, even on the basis of the new German Federal Act on Integration, the successful integration of asylum seekers, refugees, foreigners who have been granted subsidiary protection or who have been granted an initial temporary residence permit, into the German society and the German job market still has a long way to go and remains a big challenge for German politicians, public authorities, economy, and society. There is no doubt that integration measures for every immigrant with a prospect of staying in Germany are necessary and beneficial investments for their successful integration in Germany and for the German state. However, the practice shows that strict rules for integration and lacking administrative flexibility sometimes make it more difficult to provide effective integration. Therefore, after being in force for nearly 1.5 years, the German Federal Act on Integration should be critically evaluated. Taking into account the feedback from administrative authorities, job centres, employers, and immigrants themselves, it needs to be assessed how effective the new Integration Act is in practice. After this evaluation, necessary steps and adjustments should be made to improve the existing legal and practical situation of integrating foreigners into the German society and labour market.

Prof. Dr. Dr. Arndt Künnecke

Federal University of Applied Administrative Sciences

arndt.kuennecke@hsbund.de

64 See: BECKER, S. - WIEDMANN-SCHMIDT, W.: Ein Ex-Mitarbeiter des Bundesamts für Flüchtlinge packt aus. Spiegel-Online [online], 16. 10. 2017, available online at: http://www.spiegel.de/spiegel /bundesamt-fuer-migration-und-fluechtlinge-ein-ex-mitarbeiter-packt-aus-a-1172859.html [accessed on 28.12.2017]; BOK, W.: Die Flüchtlingskosten sind ein deutsches Tabuthema. Neue Zürcher Zeitung [online], 15. 9. 2017.

65 Wartezeit für Integrationskurse gestiegen. Die Welt, 24. 12. 2017, available online at: https://www.welt.de /newsticker/dpa_nt/infoline_nt/schlaglichter_nt/article171883066/Wartezeit-fuer-Integrationskurse -gestiegen.html [accessed on 28.12 .2017 ].

66 See: Wirtschaftsforscher warnt vor Spaltung der Gesellschaft. Die Welt [online], 26. 12. 2017, available online at: https://www.welt.de/wirtschaft/article171904578/Integration-von-Fluechtlingen-DIW -warnt-vor-Spaltung-der-Gesellschaft.html [accessed: 28.12.2017]. 